\title{
THE ONLY WAY IS UP: WHY HILL FARMING IS EMBRACING TECHNOLOGY
}

AS WE BECOME INCREASINGLY CONCERNED ABOUT USING THE WORLD'S RESOURCES MORE EFFICIENTLY, THE AGRICULTURE INDUSTRY'S ATTENTION IS TURNING TO THE UPLANDS. PROFESSOR DAVY MCCRACKEN OF SCOTLAND'S RURAL COLLEGE IS FOCUSING ON INTEGRATED LAND MANAGEMENT, TO ENSURE THAT THE HILLS AND MOUNTAINS OF SCOTLAND ARE MANAGED IN AS SUSTAINABLE A WAY AS POSSIBLE

\section{MAGINE THS}

A shepherd strides over a hill in Scotland, accompanied by three sheepdogs and a drone. An electronic tag in one of his sheep's ear has alerted him that a sheep has become separated from the flock, that it hasn't moved for several hours, and that the rest of the flock are now a kilometre away. By using the location coordinates in tandem with the drone's infrared camera, he spots it stuck in a gully, and manages to haul it out and reunite it with the flock.

The next day, the shepherd and his dogs herd the flock to the farmhouse to measure their weight and assess other health factors. The database informs him that the sheep that had been stuck is losing weight, and on closer inspection he sees it is suffering from a disease. He closely monitors it for the next few weeks, feeding it a special diet as well as a course of tailored antibiotics. When it has fully recovered, it returns to the flock.

Imagine innovating and developing more technologies like these to help farmers manage their land sustainably and profitably.

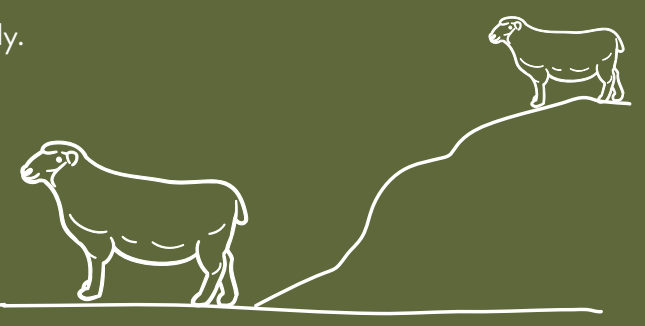

Upland farming has historically been overlooked by agricultural science compared to higheroutput, more profitable lowland farming. This has meant that technological innovations and other precision measures have, until recently, been underused in such areas. However, as we move into an age focused on sustainability and efficiency, it is probable that upland farms will come to represent a much greater proportion of animal agriculture. It is therefore very important that they are managed as effectively as possible.

Professor Davy McCracken, Head of Integrated Land Management and Head of the Hill \& Mountain Research Centre at Scotland's Rural College (SRUC), has spent several decades working on this issue. Scotland is one of the world's leading areas for sheep farming; in fact, the UK is the sixth largest producer of sheep meat (lamb and mutton) in the world. Now, integrated management techniques are helping to ensure that these areas are managed as productively and sustainably as possible.

WHY THE FOCUS ON THESE UPLAND SYSTEMS?

Around $70 \%$ of Scotland's land is mountainous or has mountainous characteristics (i.e. a similar climate or soil type), and there are limited agricultural uses to which this land can be put. "Poor soil condition combined with high rainfall means that Scotland's mountainous areas are unsuitable for ploughing or growing crops," 
Integrated land management is about combining conventional farming techniques with countryside management and the latest innovations in science and technology, as well as considering factors such as biodiversity and sustainability. This knowledge, together with the capacity to collect and interpret increasing quantities of data, gives a much broader understanding of what can be done to make farms more profitable, more sustainable and more efficient.

By understanding the factors that affect upland systems, it is easier to modify these factors in a meaningful way. The right data can help decipher the best diet for a flock, the optimum number of animals an area can support, or how to ensure positive interactions between farming and conservation measures.

WHAT ARE SOME EXAMPLES OF THE RESEARCH TAKING PLACE?

Since integrated upland management is concerned with accounting for all the players in the system, it is natural that SRUC's Hill \& Mountain Research Centre has a very broad array of projects, drawing on several scientific disciplines. As well as developing precision livestock techniques, they also research bio-economic modelling (using biology and economics to model optimal land management practices), how to integrate trees and woodlands into upland farming, and how best to mitigate upland farming's contributions to climate change and these are just the tip of the iceberg! This dispels the myth of scientific research being narrow-focused; the SRUC's goal is to see the big picture.

WHAT IS THE ROLE OF THE ENVIRONMENT IN INTEGRATED LAND MANAGEMENT?

"In upland areas, it is impossible to separate agricultural issues from environmental issues," says Davy. Uplands contain diverse ecosystems, from peatlands to native woodlands, which are home to many species of high conservation value. In the past, environmentalists have largely condemned animal agriculture for degrading and destroying natural habitat, and while that remains the case in many areas, Davy believes there is clear evidence that grazing livestock in the uplands can have strong environmental benefits. "Appropriate active management can have a positive impact on many environmental issues, such as stopping or reversing declines in biodiversity, or reducing the risk of flooding in the lowlands," he says. "Nowadays, upland livestock

systems are seen as having an important role to play in addressing the ongoing climate and biodiversity emergencies."
WHAT SORT OF PERSON WOULD SUIT A CAREER IN THE AREA?

Many people carry a preconception of agriculture as an industry dominated by practically minded, non-academic people, but Davy thinks that this idea is out of date. "The technological solutions being put in place mean that there are more and more opportunities for people interested in understanding a wide range of agricultural, biological and ecological processes through the collection and interpretation of data."

The environmental aspect of land management is also increasingly recognised. Scientists and land managers are needed to help restore peatlands, establish woodland cover and make land management overall more conservation minded. "In uplands areas at least, the focus will shift from opportunities solely in either agriculture or countryside management, towards a situation where integrated land management is the norm," says Davy.

Check out this video of Davy highlighting the range of career opportunities to secondary school pupils and their teachers: https://www.youtube.com/ watch?v=Ip8WhJbQi7c

\section{OPPORTUNITIES IN LAND MANAGEMENT}

- Several UK universities and colleges run courses in rural land management or related areas. Examples include the Royal Agricultural University, Scotland's Rural College (SRUC) and Newcastle University.

- A number of other courses can open up a career in land management. Davy recommends animal biology courses if livestock genetics interests you, ecology for understanding soil and vegetation, or engineering to get involved in technical innovations such as drones.

- SRUC hosts a wide variety of courses at college and university level, with subjects ranging from countryside management to sustainability. In many instances they offer funding to assist with student loans and other forms of hardship.

- SRUC also offers Skills Development Scotland Modern Apprenticeship programmes, which allow apprentices to gain hands-on industry experience through work-based learning.

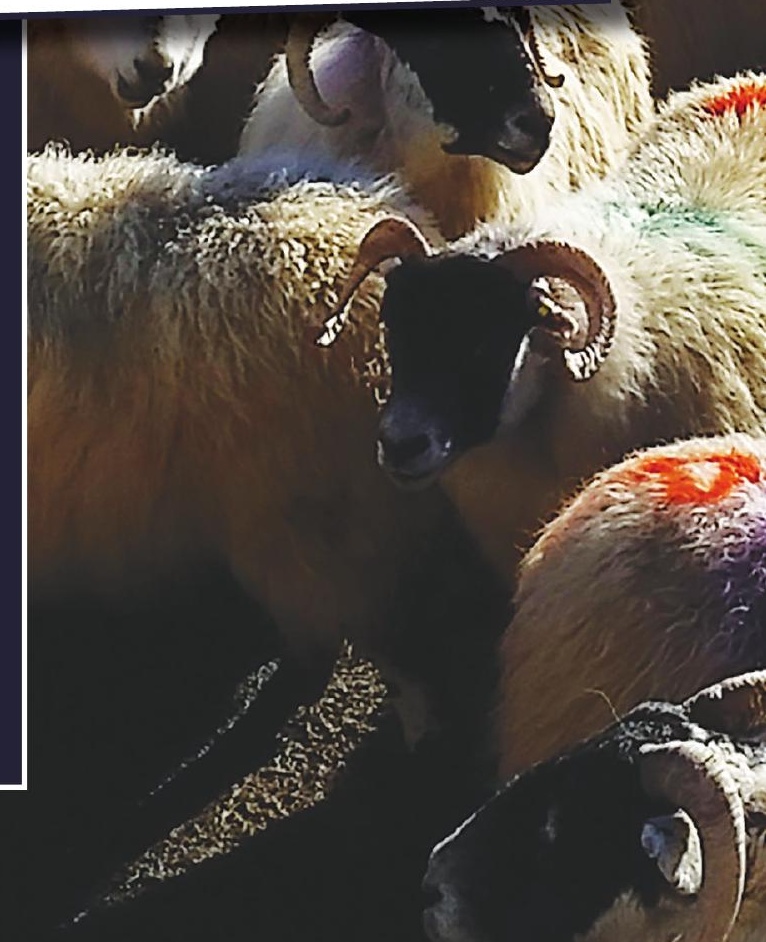




\section{-

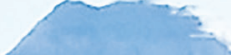 \\ ASK PROFESSOR
DAVY MCCRACKEN}

WHAT DID YOU WANT TO BE WHEN YOU WERE YOUNGER?

My dad was a shepherd on an upland farm in southern Scotland. We didn't own it, so I knew I was not going to get into farming by inheriting the farm - but I did know I wanted to do something with a farming focus. If I'm honest, however, it wasn't until after I had completed my PhD that my focus became clear.

YOU HAVE A BSC HONS IN AGRICULTURAL ZOOLOGY AND A PHD IN AGRICULTURAL ECOLOGY. WHAT DREW YOU TO THESE SUBJECTS?

I didn't study biology at secondary school until my final year, when I chose a crash course in higher biology. I loved it! And it was the combination of biology and farming that drew me to agricultural zoology, which largely focused on pests and parasites in crops and livestock. My PhD sought to understand which insects were important in the diet of a rare farmland bird (the red-billed chough), and how farm management ensured those insects were available for the bird throughout the year. Again, it was the merging of farming and wildlife, coupled with a practical, applied outcome, that drew me in.

WHAT DO YOU ENJOY MOST ABOUT THE WORK YOU DO?

This has changed throughout my career. Initially, it was all about gaining a better understanding of the interactions between farming and the wildlife on farms. I still enjoy this aspect, but over the last 20 years I have been more involved in helping to translate the findings of research into actions that farmers and land managers can undertake in the real world. Seeing these results is very fulfilling.

HOW OPTIMISTIC ARE YOU ABOUT THE ABILITY OF UPLAND LIVESTOCK SYSTEMS TO OVERCOME THE CHALLENGES THEY FACE?

I am confident that there is a future for upland livestock systems, but I believe that only those that practise a range of land management techniques and consider environmental benefits on par with agricultural products will thrive. This is why I created a Department of Integrated Land Management at the start of 2019.

\section{FINALLY, WHY DO FARMING}

COMMUNITIES NEED PEOPLE LIKE YOU TO WORK WITH THEM?

I come from a farming background but have also worked for nature conservation agencies and on agricultural and environmental policy. My background not only allows me to see the wider opportunities for farmers to increase the resilience of their farming systems, but also helps me speak to them on their own terms.

\section{DAVY'S TOP TIPS}

(1) Don't rely solely on the advice of your parents and teachers - there is a widespread lack of awareness of the opportunities that agriculture and countryside management can offer.

01 Build an understanding of the importance of collecting, analysing and interpreting data.

(1) Do your research. Seek out colleges and universities offering courses in areas such as agricultural biology, ecology or other topics that interest you, and ask what career paths these courses might open up for you.
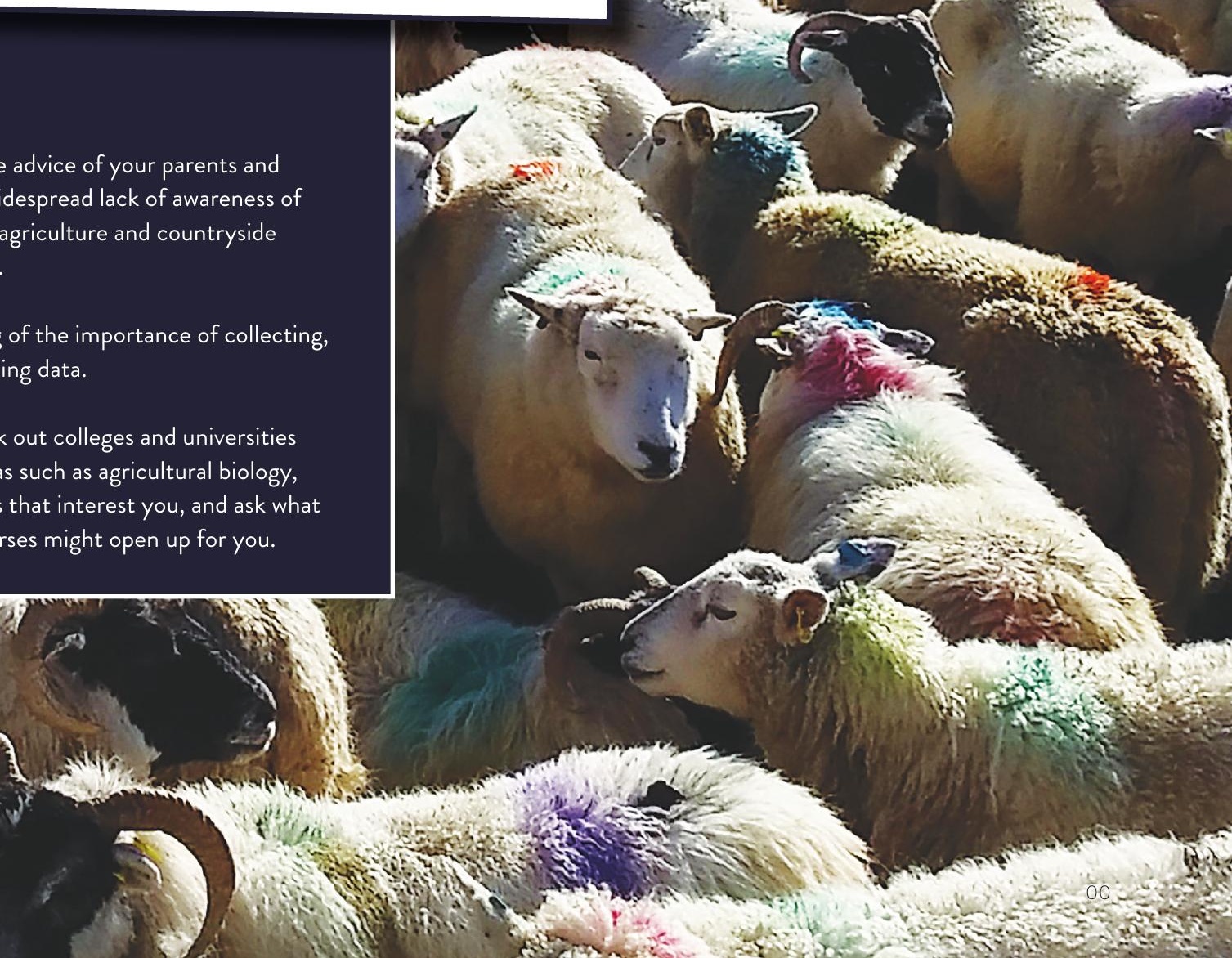